\title{
The learning ecology of Web 2.0 tool use by teacher librarian candidates
}

\author{
Cynthia Royden Houston, MLS, Ph.D.
}

\author{
Western Kentucky University \\ 1906 College Heights Blvd. \#61030 \\ Bowling Green, KY 42101-1030 \\ Cynthia.houston@wku.edu
}

\begin{abstract}
The learning ecology captured by this survey of Web 2.0 tool usage among teacher librarian candidates at Western Kentucky University paints a narrow landscape of Social networking and communication tools used for personal activities, which are used to a lesser degree in the professional and academic spheres. Results indicate that the Top five Web 2.0 tools (Social Networking, Communication, Photo/Video Sharing, Blogs, and Productivity Tools) are being used more often in professional settings than previously reported in other national and state studies. Age does not appear to be significant in the learning ecology of teacher librarian candidates' Web 2.0 tool use, indicating that an overall enthusiasm for technology among teacher librarian candidates put them in a special category of user. Suggestions for further study include exploring how "gateway" Web 2.0 tools such as collaboration and networking tools used by teacher librarian candidates in their personal lives could transfer to the professional and academic spheres, and spur motivation to use other less commonly used Web 2.0 tools such as social gaming, pod-casting or virtual environments. This study confirms that the potential for educators to integrate Web 2.0 tools into all aspects of their lives are currently hampered by limited bandwidth at home, and the use of restrictive acceptable use policies and filters in schools.
\end{abstract}

\section{Introduction}

The landscape of the World Wide Web has changed dramatically due to recent developments in collaborative and participatory Internet-based online tools collectively called Web 2.0. These tools, which include commonly used programs such as Facebook, Twitter, Flickr, Blogger, YouTube and Second Life, have transformed information development, transmission and access, along with social communication and interaction in our society. Like most technological changes, young people are quick to adapt and incorporate these new tools into their daily lives, while older adults lag behind--thus creating a technology divide between parents and their children, teachers and their students, as well as school librarians and their users. Current research indicates that the generation born between 1982 and 2002, commonly referred to as Millennials or Digital Natives, are identified as those more likely to use Web 2.0 tools for creating and accessing information (Black, 2007). As many of these Millennials have now reached adulthood and are now occupying positions as school librarians, the technology divide should be narrowing and use of Web 2.0 tools in the school library with students should be increasing. However, recent research on use of these tools shows evidence to the contrary-namely, that although many school librarians have heard of different Web 2.0 tools, a majority of them do not use them or incorporate them into their library programs (Baumbach, 2009; Farmer and Shontz, 2009).

The advent of the Web 2.0 technology tools have powerful implications for the future of teaching and learning at all levels of schooling because they define how we are to access, create, and interact with information that is increasingly found in cyberspace. If Millennials are using Web 2.0 tools in powerful ways outside the school building for self expression and social interaction, how does it affect their engagement with information inside the school building if these tools are prohibited? Furthermore, if teacher librarians do not model appropriate ways to use these tools for creating and accessing information will the Millennial generation be able to harness the full potential of Web 2.0 technology as an information resource? Most importantly, if these tools are not part and parcel of the library program, will the school library remain a viable and relevant source of information for generations to come?

As these questions are complex and ever changing, it is important that researchers continuously ask questions about what teacher librarians and students are doing in cyberspace in a systematic manner; but before the 
questions related to how and why can be posed, it is important to first determine how tools are being used for creating and accessing information in different contexts. This study provides a snapshot of Web 2.0 tool use among a specific group of adults for the purpose of identifying the nature of and relationships between the Web 2.0 tools used in their personal, professional, and academic lives. This study uses the "learning ecology" concept proposed by Barron (2006) which asserts that learning to use technology tools for personal purposes in informal or non-formal learning environments support learning in formal learning environments. In other words, Web 2.0 tools used as part of an individual's personal life have the potential for use in their professional and academic lives, and vice versa. This study will provide recommendations for how results can be used to improve the integration of Web 2.0 technologies into teaching, learning and school librarianship.

\section{Purpose of the Study}

The purpose of this study is to determine which Web 2.0 tools are being used most often by a population of K-12 teachers in Kentucky, who are also graduate students in school librarianship at Western Kentucky University. From now on, this population will be referred to as "teacher librarian candidates." The study seeks to ask questions about teacher librarian candidates' use of Web 2.0 tools in three different areas of their lives--personal, professional, and academic - to create and access information. The study uses an online survey and descriptive statistics to identify which Web 2.0 tools are used most often in each area to create and access information. Based on the results of the study, the implications for teaching and learning in classroom, school library, and professional school will be discussed. The specific research questions that will be addressed include the following:

1. What are the Web 2.0 tools used most often by teacher librarian candidates in the personal, professional, and academic areas of their lives?

2. What are the Web 2.0 tools used least often by teacher librarian candidates in personal, professional and academic areas of their lives?

3. Are there significant differences between the types and degrees of Web 2.0 tool use among respondents under 30 years of age (Millennials) and those over 31 years of age?

4. What are some of the barriers to using Web 2.0 tools in these different areas of their lives that graduate students state they experience?

\section{Background}

Information media and technology skills are a crucial part of the $21^{\text {st }}$ century skills framework. Therefore it is imperative that today's teacher librarians become effective users of $21^{\text {st }}$ century tools for creativity, productivity, and communication. Research indicates that although students are using the Internet increasingly to create and access information, there appears to be a digital disconnect when they enter the school building, even though studies have found that student engagement increases when educators integrate Web 2.0 tools into classroom learning (Reich, 2008). Several studies on youth and digital culture support the notion that students are users of information tools for learning outside the school for information seeking, information sharing, and collaboration. The Pew research studies on teens and the Internet indicate that 64 percent of K-12 students have created Web 2.0 content, with 55 percent maintaining a social networking site and 47 percent using photo and video sharing tools (Pew Internet and American Life, 2008). Based on the popularity of Web 2.0 tools with K-12 students some researchers suggest that students would be more engaged learners if there were more creative, interactive, and media oriented uses of Web 2.0 technology inside the school (Dressang, 2009; Levin, et. al. 2002; Spires, et. al., 2008).

Although $21^{\text {st }}$ century learning standards have been in place for several years and Web 2.0 tools have been in existence for a longer period of time, educators have often been criticized for making little use of Web 2.0 technology, even though students use them regularly as part of their extra-curricular activities. In Baumbach's (2009) survey of Florida school media specialists' use of Web 2.0 tools, she found that "although most library media specialists have heard of blogs and other Web 2.0 tools, a great number have never used them" (p.14). Lack of access, lack of knowledge and lack of time to learn these new tools were often cited as reasons why school librarians in Florida were not using Web 2.0 tools. Farmer and Shontz's (2009) report on Web 2.0 utilization echoed these findings on a national level. In this survey of school librarians, only 38 percent used productivity tools, 26 percent used Wikis and Blogs, 23 percent used photo and video sharing tools, less than 20 
percent of the used podcasting, 10 percent used social bookmarking sites, 4 percent used collaboration or social networking tools, and one percent used virtual environments.

Although current research indicates that Web 2.0 tools are used by a minority of school librarians, other studies suggest that if K-12 educators learn to use these tools at home or in their advanced coursework, they will be more willing to take the risk to integrate these tools into their educational programs. As an example, Sipilä's (2008) study indicates that teachers who use a laptop computer at home express a more positive attitude toward using one in the classroom. Furthermore, Brooks' (2008) study indicates that school librarians are in the majority technology enthusiasts, which makes them an ideal population for providing leadership in the use of Web 2.0 tools for teaching and learning in their schools.

The number of Web 2.0 tools available for students and school librarians to use in collaborative educational activities is growing and constantly changing. According to Black (2007), these tools are generally used for some type of collaborative writing, but others such as Skype or YouTube incorporate audio and video media formats. The categories of Web 2.0 Tools used for this study were adapted from the list provided by Common Sense Media's list of Web 2.0 tools (http://cybersmartcurriculum.org/tools/):

- Productivity and Creativity On-line Tools - these on-line tools help get work done such as creating documents and presentations, and enable collaboration. Documents can also typically be downloaded to your computer. Example: Google Docs

- Digital Storytelling Tools-These on-line tools use digital multimedia to help users create and engage in the age-old art of storytelling. Example: Zooburst

- Wikis - A Wiki is a series of web pages that, once created, can be edited and maintained by multiple users, typically as a long-term knowledge repository or database. It is usually devoted to a specific subject or field of interest. Example: Wikipedia

- On-line Surveys - On-line surveys help users create and gather information and opinions easily with minimal technical knowledge. Example: Survey Monkey

- Pod-casting - A pod-cast is a digital media file including audio and sometimes video that is syndicated, subscribed to, and downloaded automatically when new content is added. Example: Pod-casts on iTunes

- Photo and Video Sharing - Photo and video sharing services include archival media storage, public sharing, and social tagging with capabilities varying from site to site and often include a tremendous amount of quality educational content. Examples: YouTube, Flickr

- Learning Management Systems - Teaching management systems include free and open-source resources that deliver, track, and manage on-line learning. Example: Blackboard, Moodle

- RSS Feeds -RSS feeds are a convenient way to stay informed. Subscribers select Web sites and blogs and subscribe to an on-line "aggregator" service to keep track of all their news feeds in one place. Example: Google Reader

- Social Bookmarking - Social bookmarking sites store and allow users to comment on favorite Web resources and share them with others. Example: Delicious

- Collaboration and Networking - Collaboration, networking, and communication sites enable dynamic interaction among people when they work together on common goals. Social networks provide a variety of ways for users to interact. Example: Facebook, MySpace, LinkedIn, Twitter

- Blogs - A collection of web-pages authored by individuals or group members that represent a kind of "online" diary or Web-log. Example: School Library Journal Blog

- Social gaming - A simple or complex game played on-line that involves interaction between players who usually assume an on-line character or "Avatar." Example: Farmtown

- Virtual Universe - An interactive, visually rich on-line environment that mirrors the real world. Virtual worlds are created only by a community of users who assume on-line characters or "Avatars". Example: Second Life

The dynamic and changing nature of the Web 2.0 landscape can present challenges and opportunities for teachers and school librarians who struggle to find the time and resources to learn new technology skills. However, if these skills are learned by educators in their personal lives, then there is a potential for these skills to transfer into their professional and academic activities. For example, if school librarians use Facebook chat to keep up with friends outside of working hours, they may be inclined to create a Facebook page for the school 
library where students can ask questions online or to post messages about their favorite reading materials. This is an illustration of the concept of a learning ecology proposed by Barron (2006), in which all of the different learning processes and contexts overlap and influence each other. This concept is based on the premise that we are learning all the time, as part of a formal, informal, or non formal processes. When we are in education programs with specific learning goals, we are most likely engaged in formal learning processes, in which information and teaching and learning methods are focused and prescribed by specific curricular outcomes, a teacher, a software program, or learning management system (Greenhow and Robelia, 2009). When we are accessing information for reasons related to our personal interests we are engaged in what is called "non-formal learning" --a process defined by Greenhow and Robelia in which one has certain objectives in mind and actively seeks information from sources that may include peers, mentors, or media" (p. 122). When students are engaged in informal learning they are acquiring knowledge and skills for the purposes of using something new, and the learning process is more "spontaneous, experiential and unplanned" (Greenhow and Robelia, p. 122). For example, when a student contacts another student for information about how to get to the next level of a video game, they are engaged in non-formal learning. In contrast, when they learn how to upload files to a Blog for the purpose of sharing information about a particular video game, they are engaged in informal learning. Students engage in all these processes in different areas of their lives in different degrees; but because the use of formal, non-formal, and informal learning processes cut across these different areas, they provide teacher librarians with the opportunity to integrate these learning processes into content-based educational strategies (Barron, 2006). Furthermore, school librarians are in an ideal position to promote Web 2.0 tools in schools because through their expertise and role as instructional partner, they will be able to help their fellow educators match the most appropriate Web 2.0 tool to the students' learning needs (Brooks, 2008). According to Brooks (2008), knowing, modeling, and promoting Web 2.0 "not only paves the way for new collaborations, it serves to promote the role of media specialist to one of full instructional partner" (p. 16).

\section{Methodology}

In this study the concept of Web 2.0 tools learning ecology will be explored to determine the nature of and interrelationships between the use of Web 2.0 tools by teacher librarian candidates. The methodology used will be survey research. To this end, an online survey instrument was developed that included basic demographic questions and questions relating to Web 2.0 too usage based on the list of Web 2.0 tools on the Common Sense Media website (http://cybersmartcurriculum.org/tools/). Additional open ended questions relating to barriers respondents encountered in using these tools were also included. The survey was piloted in the fall of 2010 with a group of 25 students in the online section of a Reference and Information Services class. Based on this information another category of Web 2.0 Tool related to communication via telephony or chat was added to the list along with a five-point Likert scale rating scale. The final survey instrument contained 86 items, asking students to rate the degree to which they used Web 2.0 tools for personal, professional and academic purposes for creating or accessing information from "never" to "very often."

The survey was administered in the spring 2011 semester via email to a list of graduate students enrolled in online course in Library Media Education. The list of 100 students represented the total population of students taking courses in the spring 2011 semester. The initial request to complete the survey was sent in February 2011. A follow up request was sent in March 2011.

\section{Results and Discussion}

Following two request to complete the Web 2.0 tool use survey, the data was downloaded from the Qualtrics (www.qualtrics.com) survey site for analysis. A total of 38 women and 2 men between the ages of 21 and 50 responded to the survey, for an overall response rate of 40 percent. Of those who responded, 45 percent were between 21 and 30 years of age, while 43 percent were between 41 and 50 years of age. A large percentage of respondents were teachers primarily at the elementary level (40 percent) while 11 percent taught middle school and 21 percent taught high school. All of the respondents were seeking a Master of Science in Library Media Education and certification in School Library Media. In addition to the school librarian certification, 24 percent were also seeking the Instructional Computer Technology certification, which is a 12 hour concentration in educational technology. 
The data from survey responses were analyzed using descriptive statistics from SPSS (Statistical Package for the Social Sciences) software. Mean scores for each item on the survey were calculated using frequency analysis. In this study, the mean scores were used to provide a snapshot of the degree to which respondents stated they used Web 2.0 tools to create and access information for personal, professional and academic purposes. A mean score above 2.5 indicates that most respondents used the tool more than sometimes. A mean score below 2.5 indicates that respondents used the tool less than that amount. The five highest mean scores above 2.5 reported in this study included the following Web 2.0 tools: Collaboration/Networking tools, Communication tools, Photo/Video sharing and editing tools, Blogging tools, and Productivity tools. The five lowest mean scores below 2.5 reported in this study included the following Web 2.0 tools: Virtual Universe environments, Social Bookmarking sites, Social Gaming sites, RSS feeds, and Pod-casting tools. For the most part, mean scores in the Personal use area were higher than scores in the Professional and Academic Use area for both the top and bottom five Web 2.0 tools. The only exception to this was the Productivity Tools category, where mean scores for usage was higher in the Professional and Academic areas than in the Personal area of use, and Pod-casts with a higher mean score in the Academic area of use. Tables 1 and 2 below, provide a visual summary of the analysis of survey results:

\section{Table 1: Top Five Web 2.0 Tools Used (Mean Scores)}

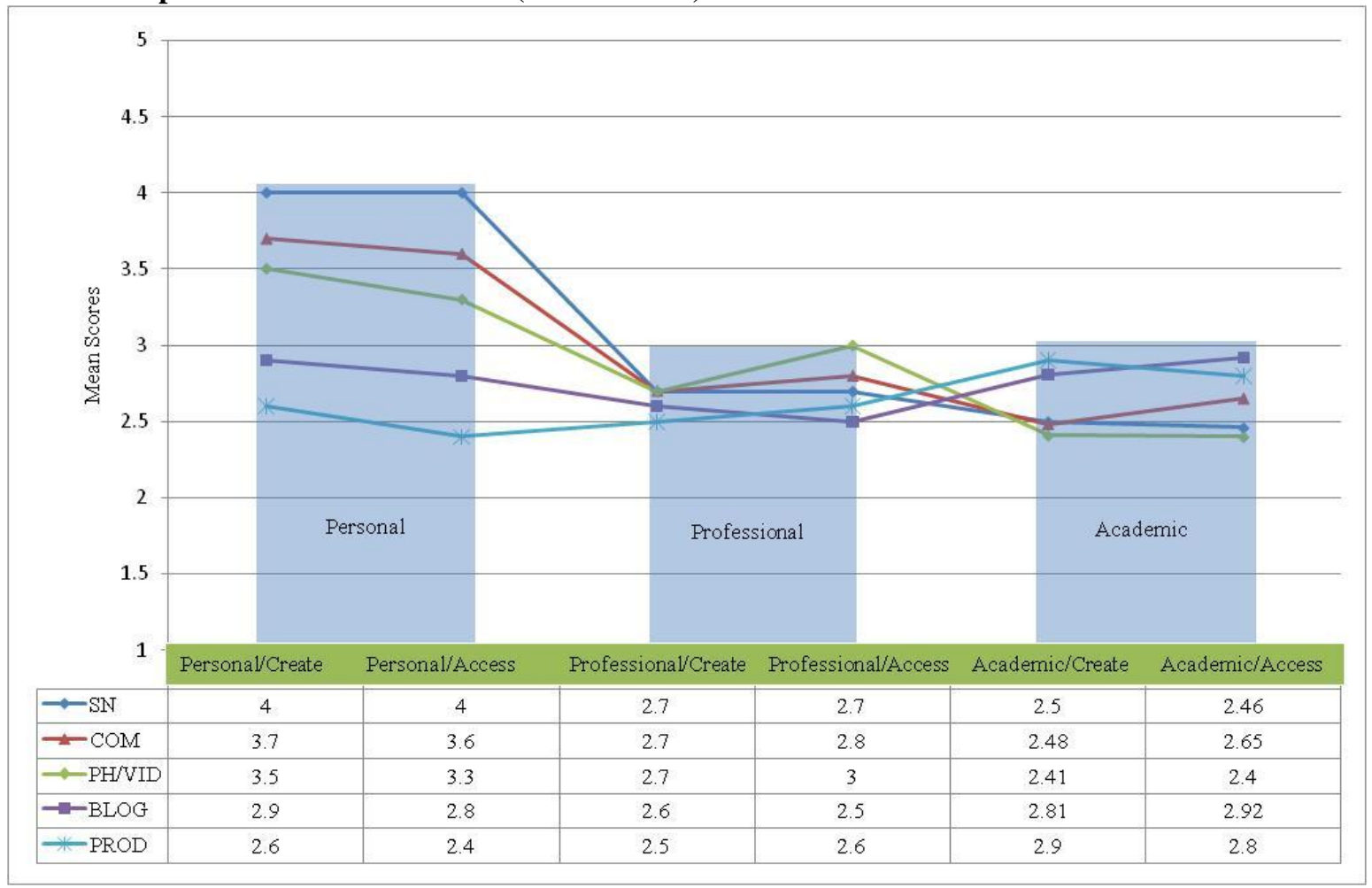

Table 2: Bottom 5 Web 2.0 Tools Used (Mean Scores) 


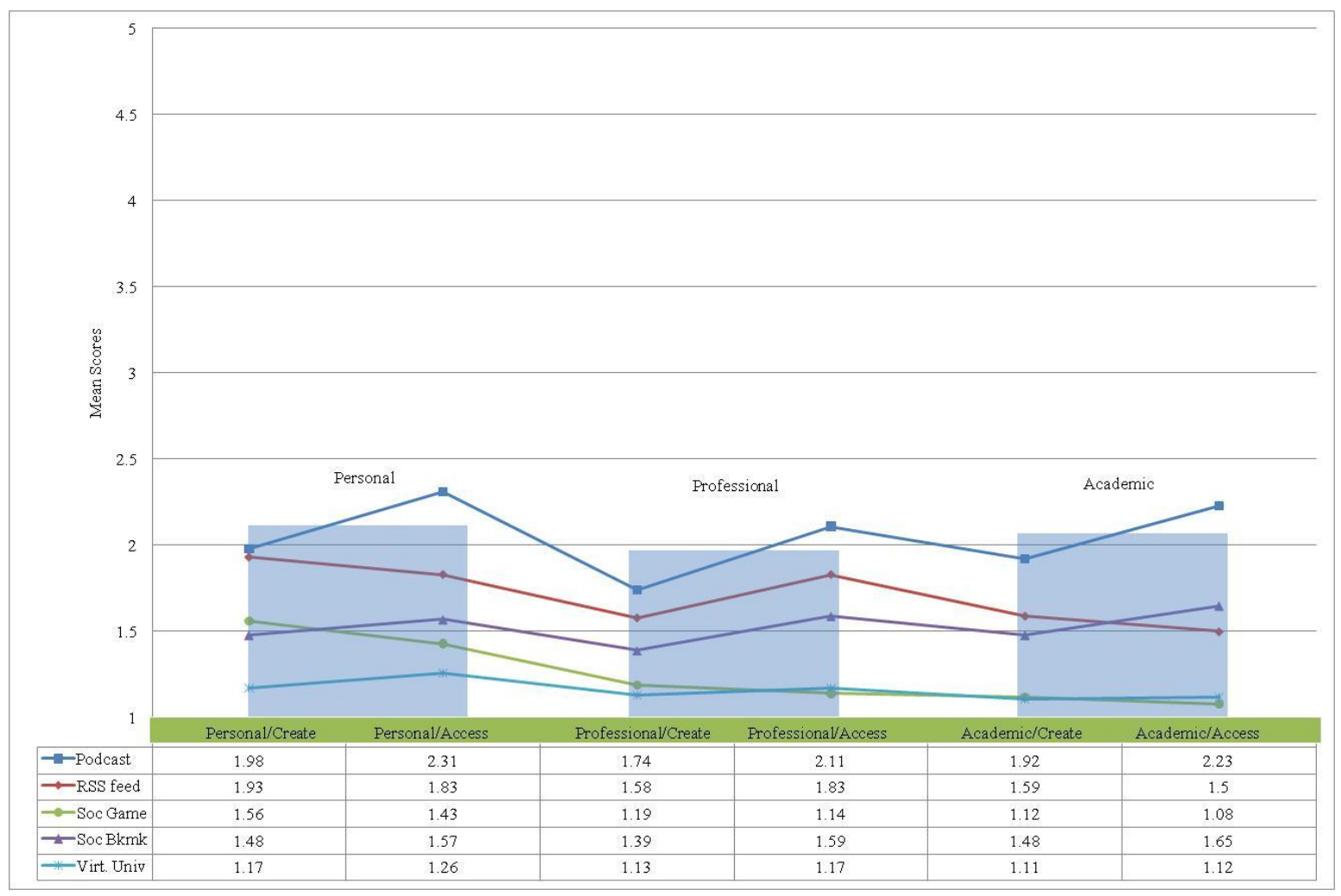

A frequency analysis was performed on the top five Web 2.0 tools teacher librarian candidates stated they used to further explore the degree to which they used these tools for accessing and creating information. As shown in Table 3 below, there is a pattern of use that runs through all of the top five Web 2.0 tools. The most frequent use of these tools is in the "sometimes," "often," and "very often" categories for creating and accessing information in their personal lives, with decreasing frequency of use in the professional and academic areas respectively. The table shows that between 70 and 80 percent of teacher librarian candidates use Collaboration/Networking tools for creating and accessing information in their personal lives between "sometimes" and "very often", while a little over 40 percent use these tools in their professional lives, and a little over 30 percent use these tools in their academic activities. This pattern holds as well with Communication tools, where between 55 and 65 percent of teacher librarian candidates use these them to create and access information in their personal lives between "sometimes" and "very often", around 45 percent use these tools in professional lives, and around 40 percent use these tools in their academic lives. Almost all the respondents used Photo/Video sharing tools to create and access information in their personal lives, with 67 percent using these tools for accessing information and 87 percent using them for creating information. In contrast, between 45 and 50 percent used photo/video Web 2.0 tools in their professional lives, and between 30 and 40 percent used them in their academic activities for creating and accessing information. There were differences in how respondents stated they used Blogs in their personal lives, with a little over 40 percent stating they used Blogs to access information between "sometimes" and "very often" and around 70 percent stating they used Blogs to create information. In their professional lives around 40 percent of respondents stated they used them for creating and accessing information between "sometimes" and "very often," while almost half the respondents stated they used them in their academic lives. There were also differences between how respondents stated they used Productivity tools, as about 34 percent stated they used them between "sometimes" and "very often" to access information and a little over 50 percent stated they used them to create information in their personal lives. In their professional lives, between 30 and 40 percent of the respondents stated they used Productivity tools for creating and accessing information while around 50 percent of respondents stated they used these tools in the academic area of their lives. 
Table 3: Frequency Charts of Top Five Web 2.0 Tools Used (in Percent) Collaboration/ Networking

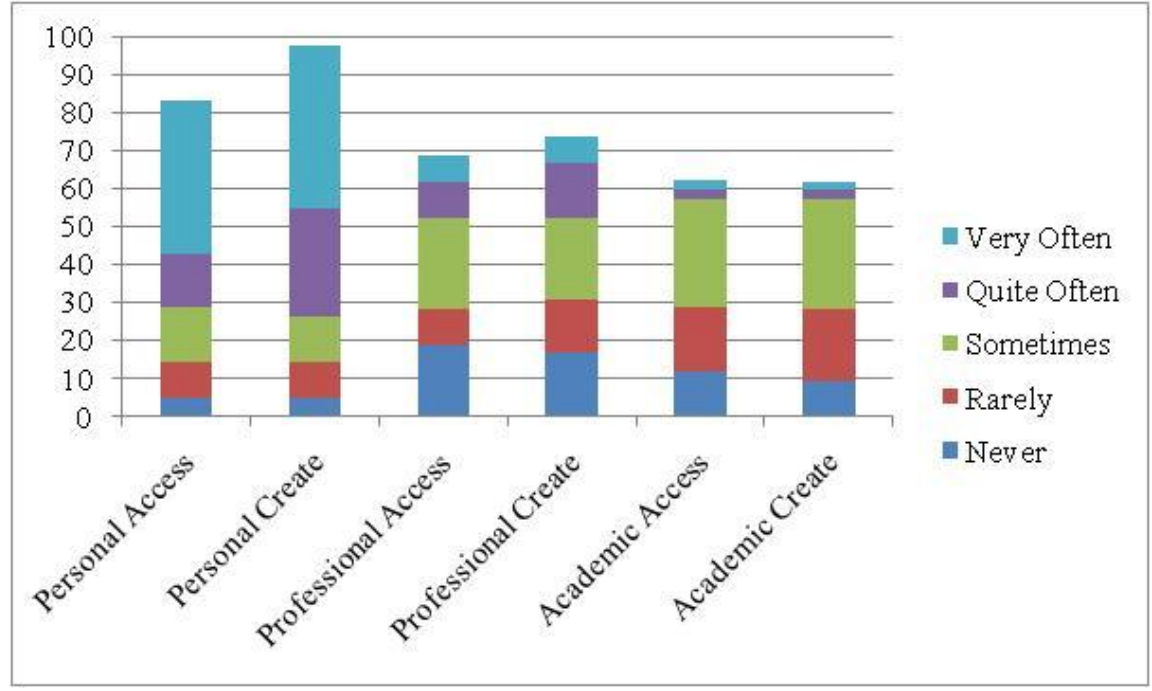

\section{Communication}

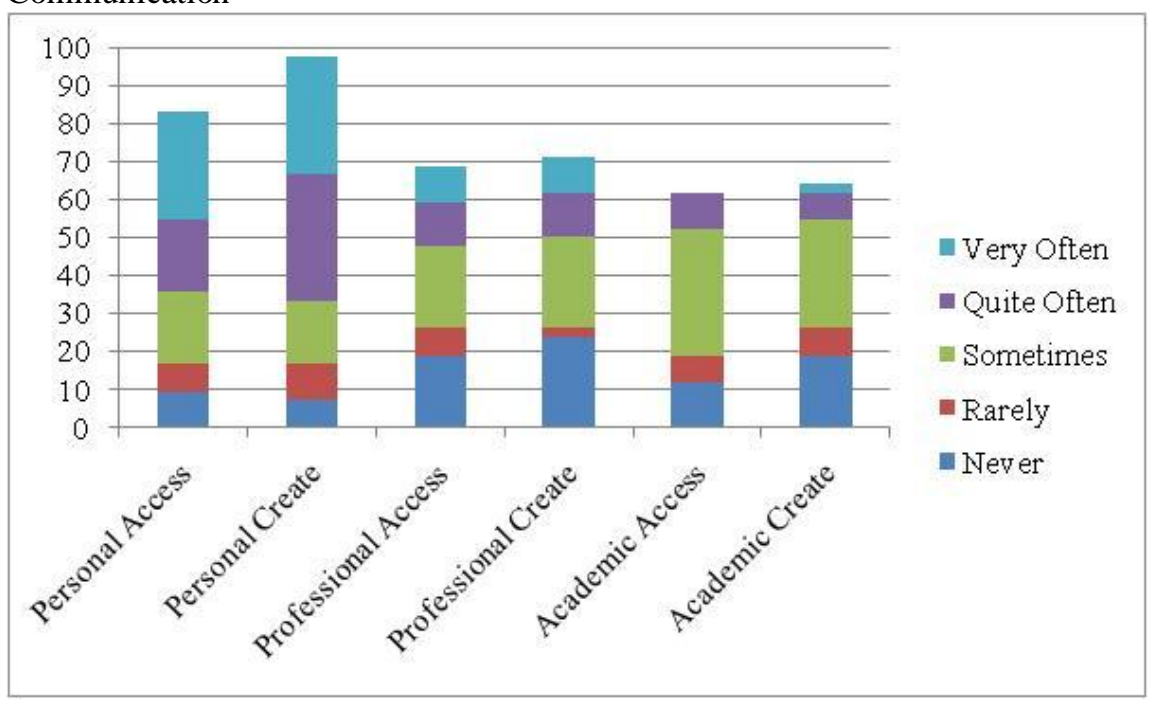


Photo/Video Sharing

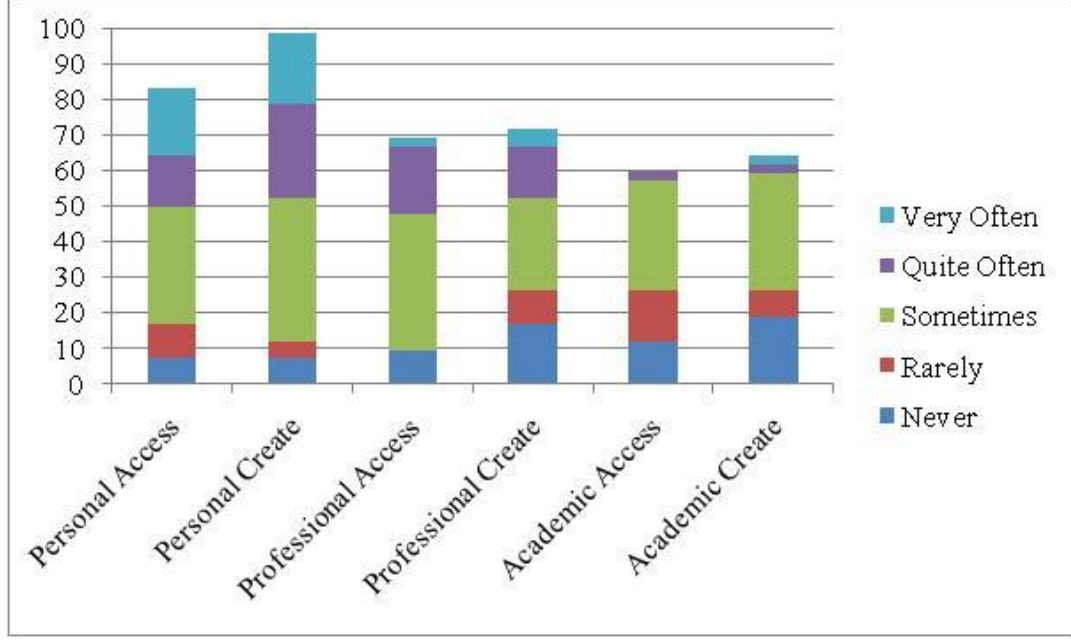

\section{Blogs}

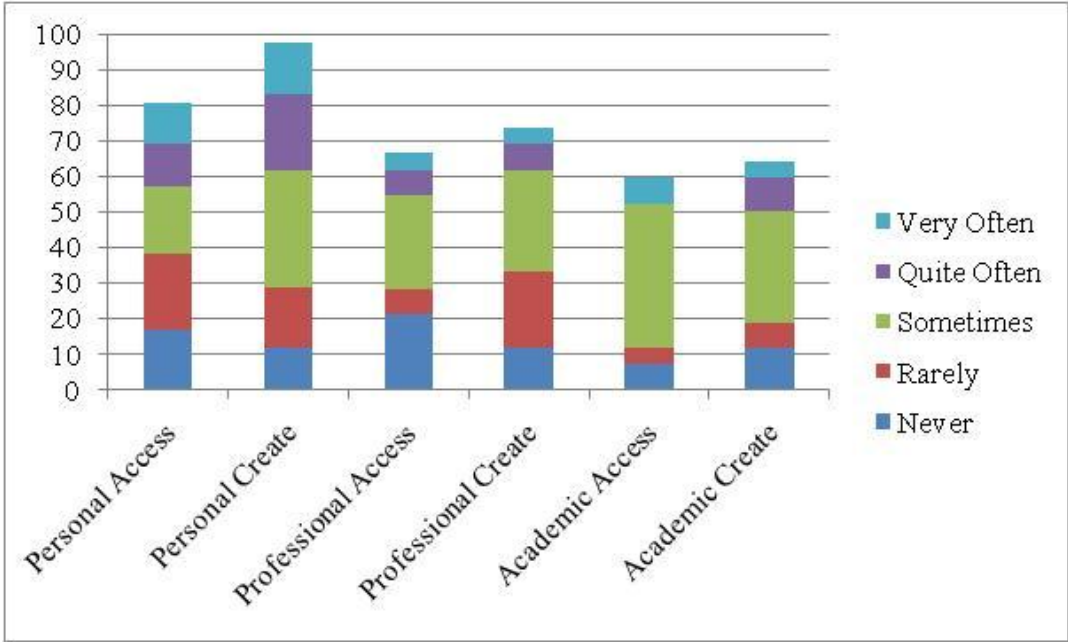

Productivity Tools

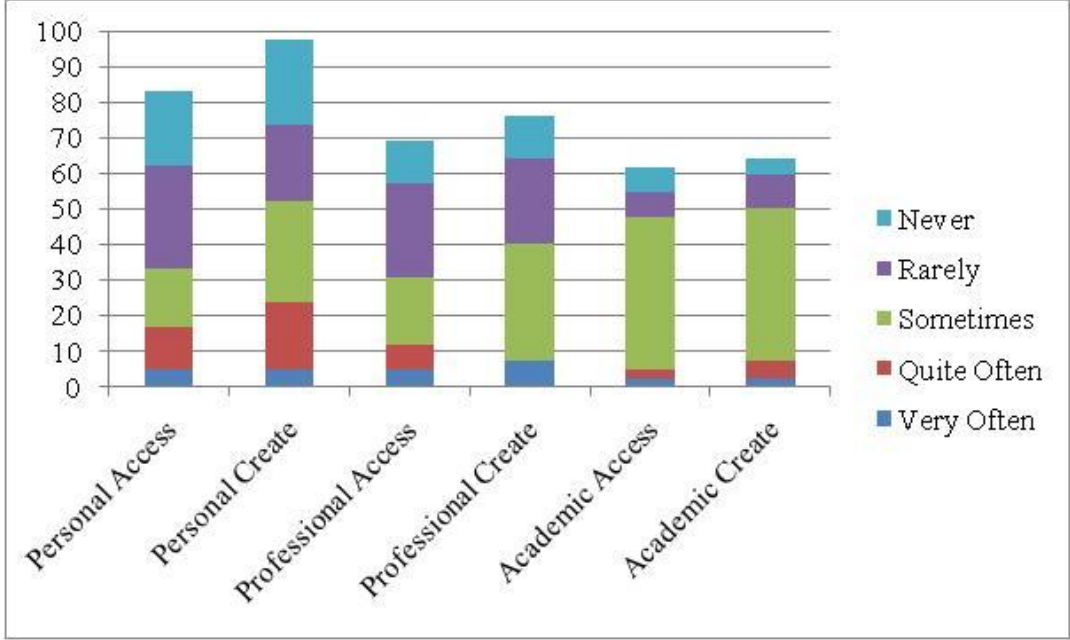


To determine if there were differences between how respondents in different age groups used Web 2.0 tools, a 2tailed T test was performed on two groups - respondents who were 30 years of age and younger and respondents who were 31 years of age and older. Overall, this analysis did not show there were any differences between these two groups. No significant differences existed except in the use of Productivity tools to create information for personal use $(x=2.62, t=.03)$ and the use of RSS feeds to access information for personal use $(x=1.67, t=.05)$ by respondents who were 30 years of age or younger.

As part of the survey, students were also asked to list any barriers they experienced to using these tools in their personal, professional, and academic lives. There were a total of 38 responses in these areas. Although, a majority of students did not respond to this part of the survey, responses to these open ended questions did fall into a pattern. In their personal lives, personal time, general knowledge of Web 2.0 tools, and the quality of their Internet service was a barrier to using Web 2.0 tools. In the professional area, again knowledge and lack of time, along with the use of filtering software in schools and acceptable use policies prevented the use of many of the collaboration and networking tools they commonly use in their personal lives. In their academic lives students also listed lack of time, knowledge and access as limiting factor. Table 4 lists selected responses to this part of the survey. 
Table 4: Selected Responses to Open Ended Questions on Barriers to Web 2.0 Tool Use

\begin{tabular}{|c|c|c|c|}
\hline & Personal & Professional & Academic \\
\hline Lack of Time & $\begin{array}{l}\text { The amount of time } \\
\text { left over after work } \\
\text { and classes, does not } \\
\text { leave very much time } \\
\text { for personal ventures } \\
\text { using technology. } \\
\text { I really don't know of } \\
\text { any barriers, other } \\
\text { than the time factor. I } \\
\text { just don't have a lot } \\
\text { of time to use these } \\
\text { features right now. }\end{array}$ & $\begin{array}{l}\text { Lack of time to explore and understand how } \\
\text { Web } 2.0 \text { tools could be best utilized in the } \\
\text { classroom }\end{array}$ & $\begin{array}{l}\text { time to explore and understand } \\
\text { how Web } 2.0 \text { tools could be used }\end{array}$ \\
\hline $\begin{array}{l}\text { Lack of } \\
\text { Access }\end{array}$ & $\begin{array}{l}\text { I have DSL and } \\
\text { connection speed is } \\
\text { sometimes slow on } \\
\text { videos } \\
\text { cost of } \\
\text { Internet }\end{array}$ & $\begin{array}{l}\text { student access to Internet/computers at home } \\
\text { computers down } \\
\text { Finding enough computers that work for a } \\
\text { class to use the tools. } \\
\text { Cost of materials }\end{array}$ & $\begin{array}{l}\text { The fact that I work full time in a } \\
\text { school setting and the fact that } \\
\text { many resources that need to be } \\
\text { accessed for classes are blocked } \\
\text { on the school computers. } \\
\text { YouTube for example. } \\
\text { Wireless internet connection } \\
\text { interrupted. }\end{array}$ \\
\hline $\begin{array}{l}\text { Lack of } \\
\text { Knowledge }\end{array}$ & $\begin{array}{l}\text { Awareness of what is } \\
\text { out there and } \\
\text { knowing how to use } \\
\text { it or for what } \\
\text { purpose; } \\
\text { lack of knowledge in } \\
\text { some Web } 2.0 \text { tools }\end{array}$ & $\begin{array}{l}\text { I didn't know all of the Web } 2.0 \text { tools that } \\
\text { were available. } \\
\text { Lack of knowledge in some Web } 2.0 \text { tools to } \\
\text { be able to use them in the most effective } \\
\text { way. }\end{array}$ & $\begin{array}{l}\text { understanding the aspects } \\
\text { Lack of experience. } \\
\text { Lack of knowledge in some Web } \\
2.0 \text { tools to be able to use them in } \\
\text { the most effective way. }\end{array}$ \\
\hline $\begin{array}{l}\text { Online } \\
\text { Security } \\
\text { Issues }\end{array}$ & $\begin{array}{l}\text { Feeling safe to } \\
\text { connect with people I } \\
\text { do not know }\end{array}$ & $\begin{array}{l}\text { The largest barrier in professional life is the } \\
\text { fact that many web } 2.0 \text { tools are blocked on } \\
\text { our school network. Often times a web } 2.0 \\
\text { can be accessed one time, then if you go } \\
\text { back to use it, it has been blocked. } \\
\text { Internet filtering software (i.e., Websense) } \\
\text { Many times we are not able to access Web } \\
2.0 \text { tools due to our AUP and the X-stop } \\
\text { function in our district that prevents us from } \\
\text { accessing certain site. } \\
\text { Students who misuse computers } \\
\text { Many sites are blocked at my school, so I do } \\
\text { not have access to many Web } 2.0 \text { tools. }\end{array}$ & \\
\hline $\begin{array}{l}\text { Lack of } \\
\text { Engagement }\end{array}$ & & $\begin{array}{l}\text { ability to get students able to participate in } \\
\text { web } 2.0 \text { tools }\end{array}$ & $\begin{array}{l}\text { Being able to implement some of } \\
\text { the activities in my classroom }\end{array}$ \\
\hline
\end{tabular}




\section{Conclusions and Recommendations}

The conclusions that can be reached from this study are limited by the non-random sample size and the low response rate. These factors may bias the results of the study in favor of particular tools or modes of use. In addition, the population for this study, namely teacher librarian candidates in an online program at Western Kentucky University may not reflect the same characteristics of a wider population of educators or school librarians.

The results of this study indicate that there are many fruitful areas for discussion and further research related to Web 2.0 tool use in teacher librarian candidates' personal, professional, and academic lives. Findings from this study indicate that the Top five Web 2.0 tools are being used more often in professional settings than previously reported in state and national studies (Baumbach, 2009; Farmer and Shontz, 2009). The learning ecology captured by this study paints a narrow virtual landscape of Social networking and Communication tools used for personal activities, which are used to a lesser degree in the professional and academic spheres. Age does not appear to be significant in the learning ecology of teacher librarian candidates' Web 2.0 tool use, indicating that an overall enthusiasm for technology described by Brooks (2008) may put this group of educators into a special category of user.

The results of this study tend to confirm Barron's (2006) concept of a learning ecology, in which modes and tools for learning cut across areas of an individual's life when they have an interest and motivation to develop skills or knowledge in a particular area. Perhaps the collaboration and networking tools used by teacher librarian candidates in their personal lives may represent "gateway" tools for future incorporation into professional and academic arenas, and spur interest in exploring less commonly used tools such as social gaming, pod-casting or virtual environments.

Although results of this study support Barron's learning ecology paradigm, the ability for educators to integrate Web 2.0 tools into all aspects of their lives are currently hampered by limited bandwidth at home, and the use of restrictive acceptable use policies and filters in schools. The results of this study confirm earlier findings by Baumbach (2009) that restrictions on Web 2.0 tools use in schools greatly diminish their potential use as an educational resource. Furthermore, findings showing less frequent use of Web 2.0 tools in the academic area could be due to Learning Management Systems that incorporate many of these tools into their password protected platforms or to limited faculty use of Web 2.0 tools in their instructional activities.

Although this study indicates that at this point in time teacher librarian candidates at WKU are not making full use of the Web 2.0 tools available, this study also shows that use of particular tools tend to cut across areas of personal, professional and academic life. This fact offers a potential for widening the learning ecology of teacher librarian candidates through professional development and academic coursework. For example, although Web 2.0 tools such as Virtual Environments, Social Gaming, and Pod-casting are widely touted in school librarian circles as a mode of delivery for educational information, in reality, teacher librarian candidates are making very little use of them. This issue could be ameliorated through the integration of these tools into instructional activities in academic coursework and professional development programming.

The results of this survey also confirm the findings of other research studies, indicating that acceptable use policies and Internet filtering software restrict the educational use of important Web 2.0 tools. The current state of affairs which limit the use of participatory and collaborative social networking tools in schools is exacerbating the technological divide between teachers, librarians and their students. How can a participatory and collaborative online learning environment develop if students and teachers are not allowed to access this world at school? If as educational researchers and scholars have indicated, that students would feel more engaged with educational content in a Web 2.0 world, and as Web 2.0 tools become an increasing part of every dimension of our lives, then to maintain the technology divide between schools and the Web 2.0 universe poses a danger to the relevance and viability of schooling in our society.

Finally, if the school library is the center for innovation in teaching, learning and technology in the school, and the engine behind $21^{\text {st }}$ century modes of learning, the implication that teacher librarian candidates are not making 
full use of Web 2.0 tools in their personal, professional, and academic lives is a concern. As we move further into the $21^{\text {st }}$ century, the use of Web 2.0 tools in the school library will be a critical part of the $21^{\text {st }}$ century learning ecology. School librarians must provide the leadership for developing effective, creative and innovative users of information and ideas, for ensuring all students are equipped with 21 st century knowledge and skills for accessing digital information, and most importantly, for fostering a participatory and collaborative educational environment which will be relevant to current and future Digital Natives.

Three key learnings:

- The top five Web 2.0 tools teacher librarians use most often are Collaboration/Networking tools, Communication tools, Photo/Video sharing and editing tools, Blogging tools, and Productivity tools.

- The top five Web 2.0 teacher librarians use least often are Virtual Universe environments, Social Bookmarking sites, Social Gaming sites, RSS feeds, and Pod-casting tools.

- Teacher librarian candidates use Web 2.0 most often in their personal lives, and decreasingly in their professional and academic lives.

- There were no significant differences in Web 2.0 tool usage by the "Millennial" teacher librarian candidates except for Productivity Tools and RSS Feeds.

- Teacher librarian candidates listed limited bandwidth at home, lack of time and knowledge, and filtering at work as barriers to their use of Web 2.0 tools.

\section{References}

Barron, B. 2006. Interest and self-sustained learning as catalysts of development: A learning ecologies perspective. Human Development, 49, 193-224.

Baumbach, D. J. (2009). Web 2.0 \& You. Knowledge Quest, 37(4), 12-19. Retrieved from EBSCOHost.

Black, E. (2007) Web 2.0 and Libraries 2.0: What librarians need to know. In N. Courtney (Ed.), Library 2.0 and beyond: Innovative technologies and tomorrow's user. Westport, CT: Libraries Unlimited.

Brooks, A. (2008). Old school meets school library 2.0: bump your media program into an innovative model for teaching and learning. Library Media Connection 26 (7), 14-16. Retrieved from EBSCO Host.

Dressang, E. \& Koh, K. (2009). Radical change theory, youth information behavior, and school libraries. Library Trends 58(1), 26-50. Retrieved January 22, 2011, from Project MUSE database.

Farmer, L. \& Shontz, M. (2009). Spending survey. School Library Journal, 55(4), 35-44. Retrieved from EBSCO Host.

Greenhow, C., \& Robelia, B. (2009). Informal learning and identity formation in online social networks. Learning, Media \& Technology, 34(2), 119-140. doi:10.1080/17439880902923580

Kulyk, T. (2010). My vision as a new teacher librarian. Literacies, Learning \& Libraries, 1, 24-27 Retrieved from

http://albertaschoollibraries.pbworks.com/f/LiteraciesLearningLibraries+Vol3No1+pdf.pdf\#page=34

Levin, D., Arafeh, S., Lenhart, A., and Rainie. L. (2002). The digital disconnect: The widening gap between internet-savvy students and their schools. Washington, DC: Pew Charitable Trust. http://www.pewinternet.org/PPF/r/67/report_display.asp (accessed October 1, 2008).

Pew Internet and American Life. (2008). Writing, technology, and teens. Retrieved from http://www.pewinternet.org/Reports/2008/Writing-Technology-and-Teens.aspx.

Reich, J. (2008). Reworking the web, reworking the world: How web 2.0 is changing our 
society. Beyond Current Horizons. Retrieved from www.beyondcurrenthorizons.org.uk

Sipilä, K. (2008). Mobile technology and teachers' attitudes towards ICTs in basic education. In Luca \& Weipple (Eds.), Proceedings of the World Conference on Educational Multimedia, Hypermedia and Telecommunications 2008 (pp. 3270-3278). Chesapeake, VA: AACE.

Spires, H, Lee, K, Turner, K, and Johnson, J. (2008). Having our say: Middle grade student perspectives on school, technologies, and academic engagement. Journal of Research on Technology in Education, (40) 4, 497-515.

\section{Biographical Note}

Cynthia Houston is an Associate Professor in the Western Kentucky University Library Media Education Program. Her research interests include regional children's literature, bilingual books, international comparative librarianship, and $21^{\text {st }}$ century learning landscapes.

\section{Statement of Originality}

This statement certifies that the paper above is based upon original research undertaken by the author and that the paper was conceived and written by the author(s) alone and has not been published elsewhere. All information and ideas from others is referenced. 